TAO, Vol. 10, No. 4, 693-704, December 1999

\title{
Estimates of the Contribution of Below-cloud Scavenging to the Pollutant Loadings of Rain in Taipei, Taiwan
}

\author{
Neng-Huei Lin ${ }^{1}$ and Chi-Ming Peng ${ }^{1}$ \\ (Manuscript received 5 November 1998, in final form 6 October 1999)
}

\begin{abstract}
In this study, we use a simple and semi-quantitative scheme to estimate the contribution (denoted as $f$ ) of below-cloud scavenging of pollutants by raindrops, based on the precipitation chemistry collected in Taipei City and the cloud chemistry observed at the peak of the Mt. Bamboo (around $1100 \mathrm{~m} \mathrm{MSL}$ ) in the winters of 1996-1998. The magnitudes of $f$ (nss (nonsea salt)- $\left.\mathrm{SO}_{4}{ }^{-}\right), f\left(\mathrm{NO}_{3}{ }^{-}\right)$and $f\left(\mathrm{NH}_{4}{ }^{+}\right)$were estimated to range between 0.31 $0.88,0.25-0.88$ and 0.54-96, respectively. For instance, 54-96\% of the $\mathrm{NH}_{4}^{+}$ ions in rainwater arose by below-cloud scavenging, reflecting their origins from local sources. For most of the cases, at least $75 \%$ of the $\mathrm{NO}_{3}^{-}$was accounted for by the same scavenging mechanism, whereas more than $25 \%$ of nss-SO ${ }_{4}^{2-}$ resulted from in-cloud scavenging. In comparison with $\mathrm{NH}_{4}^{+}$ and $\mathrm{NO}_{3}^{-}$, relatively higher amounts of nss- $\mathrm{SO}_{4}{ }^{2 \cdot}$ obviously derived from long-range transport.
\end{abstract}

(Key words: Below-cloud scavenging, Cloud chemistry, Precipitation chemistry, Sulfate and nitrate)

\section{INTRODUCTION}

In recent years, the chemistry of mountain clouds (Saxena and Lin, 1990; Collett et al., 1991; Schemenauer et al., 1995) and fogs (Fuzzi et al., 1992; Worbrock et al., 1994; Choularton et al., 1997) has been investigated through ground-based observations in North America and Europe. The results have generally shown that the fog/cloud water was more acidic than rainwater and had higher ionic concentrations. Outside of these areas, less attention has been paid to this topic, thus it has been rarely studied. However, in northern Taiwan (see Fig. 1), wet deposition of sulfates and nitrates has been assessed (Chen et al., 1996) to be more than twice the maximum values observed in the eastern USA (NAPAP, 1991). High loadings of sulfates were found (Chen et al., 1996) to be associated with frontal passages and northeast monsoon flows, especially during the winter seasons, indicating the possibility of the longrange transport of sulfur compounds. Under such weather conditions, low clouds (cloudbase

\footnotetext{
${ }^{1}$ Department of Atmospheric Sciences, National Central University, Chung-Li, TAIWAN, ROC
} 
(a)

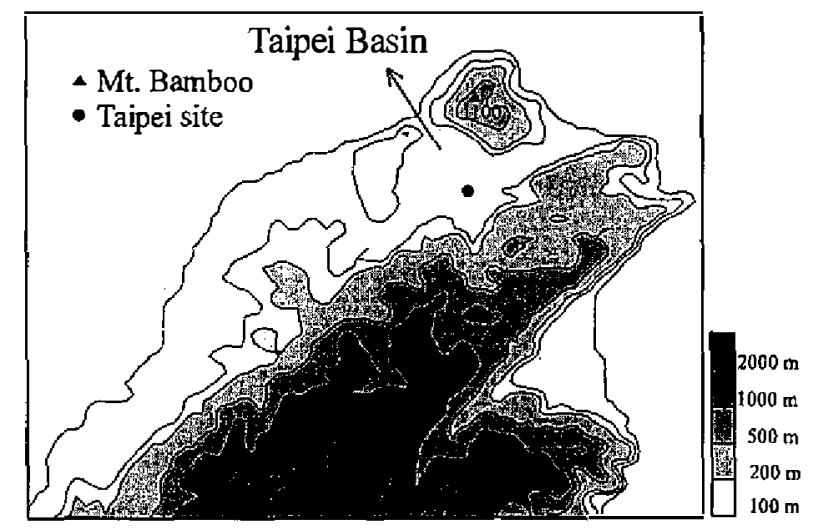

(b)

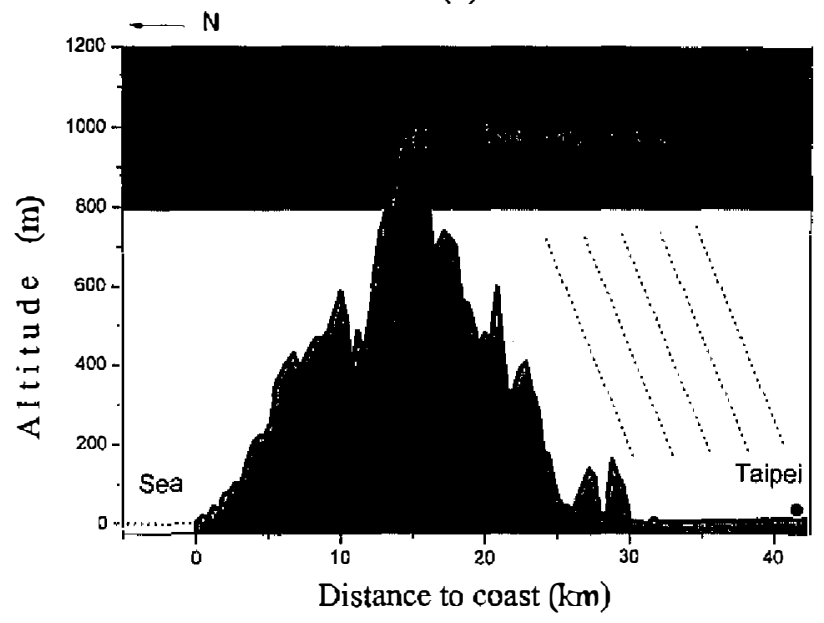

Fig. 1. (a) Location of the Mt. Bamboo site (marked as $\Delta$ ) and Taipei site (denoted by ".") for collection of cloud water and rainwater, respectively, and (b) cross-sectional illustration of above two sites.

can be as low as $600 \mathrm{~m} \mathrm{MSL}$ ) frequently cap the mountains in the very northern part of Taiwan. Upon formation, clouds are very efficient scavengers of air pollutants if they lead to precipitation subsequently, while upon dissipation, in the absence of precipitation, they efficiently transform and redistribute the air pollutants in the planetary boundary layer (Leaitch et al., 1983; Hegg and Hobbs, 1986; Schumann et al., 1988). Thus, in this paper we use a semiquantitative scheme to examine the relationship between the chemistry of clouds observed at the peak of Mt. Bamboo (see Fig. 1) and the precipitation chemistry concurrently collected at ground level in Taipei City in order to assess the contribution of below-cloud scavenging of pollutants by raindrops to the chemical composition of rainwater. 


\section{EXPERIMENTAL SETUP}

The cloud water was collected at the peak (about 1100m MSL) of the Mt. Bamboo, as part of the Yang-Ming-Shan National Park, during the winter seasons (late January-early March) of 1996-1998 as the northeast monsoon flows prevailed. Figure 1 depicts the location of the experimental site (marked by $\mathbf{A}$ ). It is noted that the site is frequently immersed in clouds which form either due to frontal passage or topographic effects. The temperatures at our site were recorded as $9.0 \pm 3.7^{\circ} \mathrm{C}$ during the field seasons. The lowest temperature recorded was near $0^{\circ} \mathrm{C}$. The wind speed, on average, was about $7.0 \mathrm{~m} \mathrm{~s}^{-1}$ and can reach as high as $20 \mathrm{~m} \mathrm{~s}^{-1}$. Figure 2 shows a case of frontal passage over northem Taiwan at 00UTC on February 4, 1998. As shown on the infrared satellite image, the frontal clouds extended from southern China to northwest Pacific Ocean. The clouds were well organized and distributed in accordance with the location of fronts (see Fig. 2). Figure 3 further depicts the average streamlines over the northern part of Taiwan during the winter seasons (Chen and Tseng, 1983). It can be seen that prevailing flows to the site are northerly. Meanwhile, convergence generally formed inside the Taipei basin. Therefore, during the northeast monsoon seasons, in consideration of its location and altitude (see Fig. 1), this site should be free from local pollutants, which are primarily emitted from Taipei basin. Therefore, we assume that the cloud water collected at our site should not be contaminated by local anthropogenic emissions such as sulfur and nitrogen compounds, when northerly flows prevail during the field seasons.

Cloud water was collected hourly at the roof of a building, about $4 \mathrm{~m}$ above ground level during the cloud events. The cloud event was signaled when a nearby radio tower, at a distance of about $30 \mathrm{~m}$ from observation point, was immersed in clouds and stayed consistently out of view for more than $15 \mathrm{~min}$. We used the collector of ASRC (Atmospheric Science Research Center, State University of New York) type (Katz and Miller, 1985) for cloud water collection. The collector was covered by a plastic bag when not in use and was cleaned with deionized water before deploying for collection. The $\mathrm{pH}$ of cloud water was measured immediately after collection. Thereafter, samples were refrigerated at $4{ }^{\circ} \mathrm{C}$ and shipped to National Central University for later chemical analysis. The cloud water was analyzed for ion concentrations of $\mathrm{Cl}^{-}, \mathrm{NO}_{3}, \mathrm{SO}_{4}{ }^{2-}, \mathrm{NH}_{4}^{+}, \mathrm{Na}^{+}, \mathrm{K}^{+}, \mathrm{Mg}^{2+}$, and $\mathrm{Ca}^{2+}$ using Ion Chromatography (Dionex-100). The $\mathrm{H}^{+}$was converted from the measured $\mathrm{pH}$. The QA/QC (Quality assurance and quality control) protocol for chemical analysis was based on the recommendation by GAW/ WMO (Global Atmosphere Watch/World Meteorological Organization, see Mohnen el al., 1994). Additionally, collection of rainwater was also performed on a daily basis near downtown Taipei City using a wet/dry collector (see Jeng, 1998; Lin et al., 1999). The location of the site is marked by "•" in Fig. 1. The sampling and analysis protocols of rainwater were based on the recommendations by the USA NADP/NTN (National Atmospheric Deposition Program/National Trends Network). A description and references can be found elsewhere (see Lin et al., 1999).

\section{RESULTS AND DISCUSSION}

Table 1 lists the information of six cloud events observed at our site during which concur- 
(a)

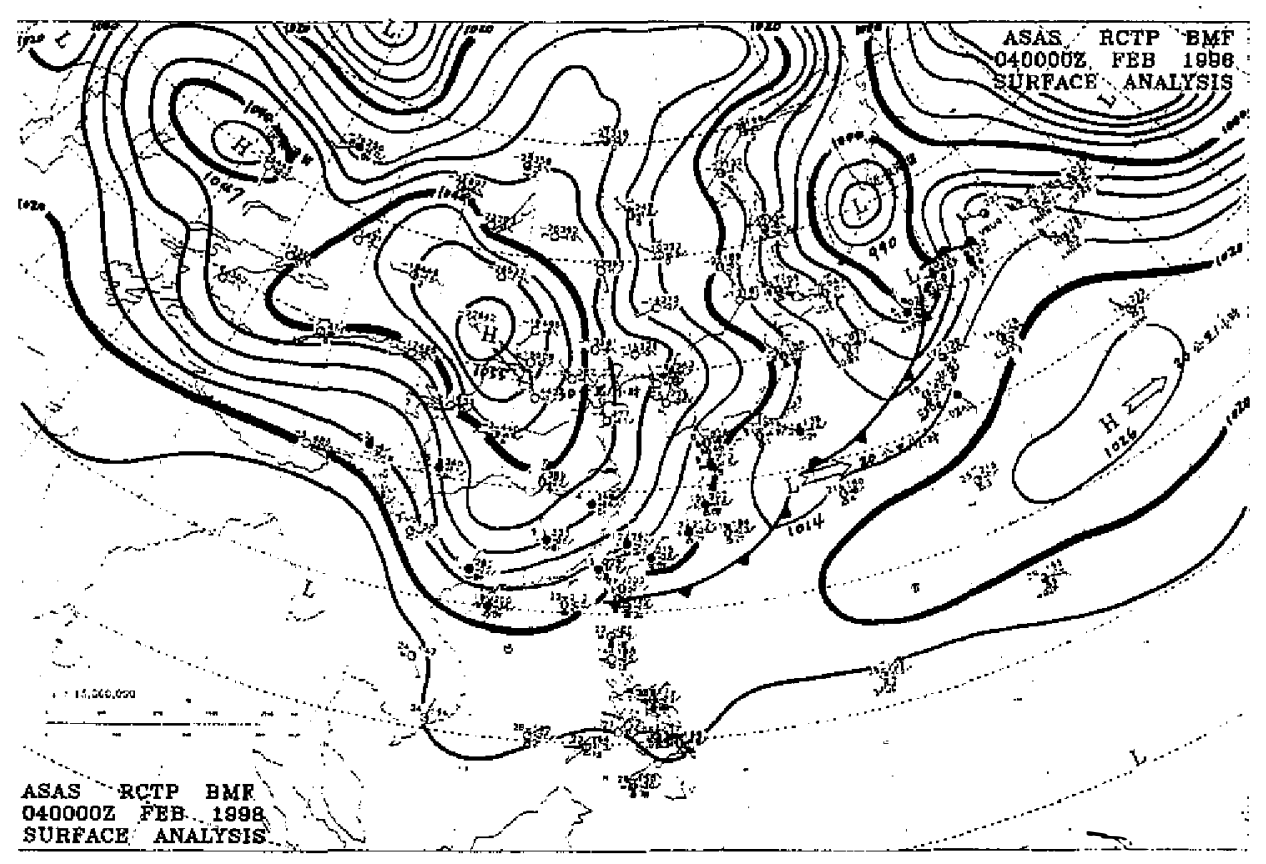

(b)

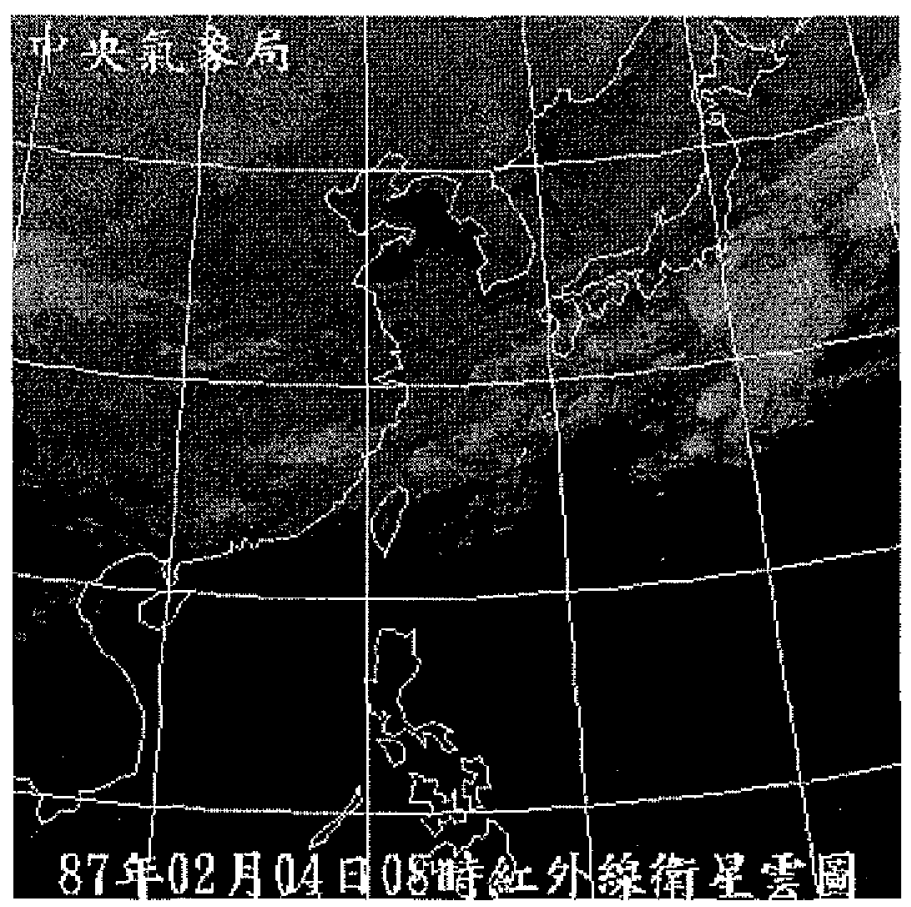

Fig. 2. (a) The surface weather map, and (b) infrared satellite image at 00 UTC on February 4, 1998. 


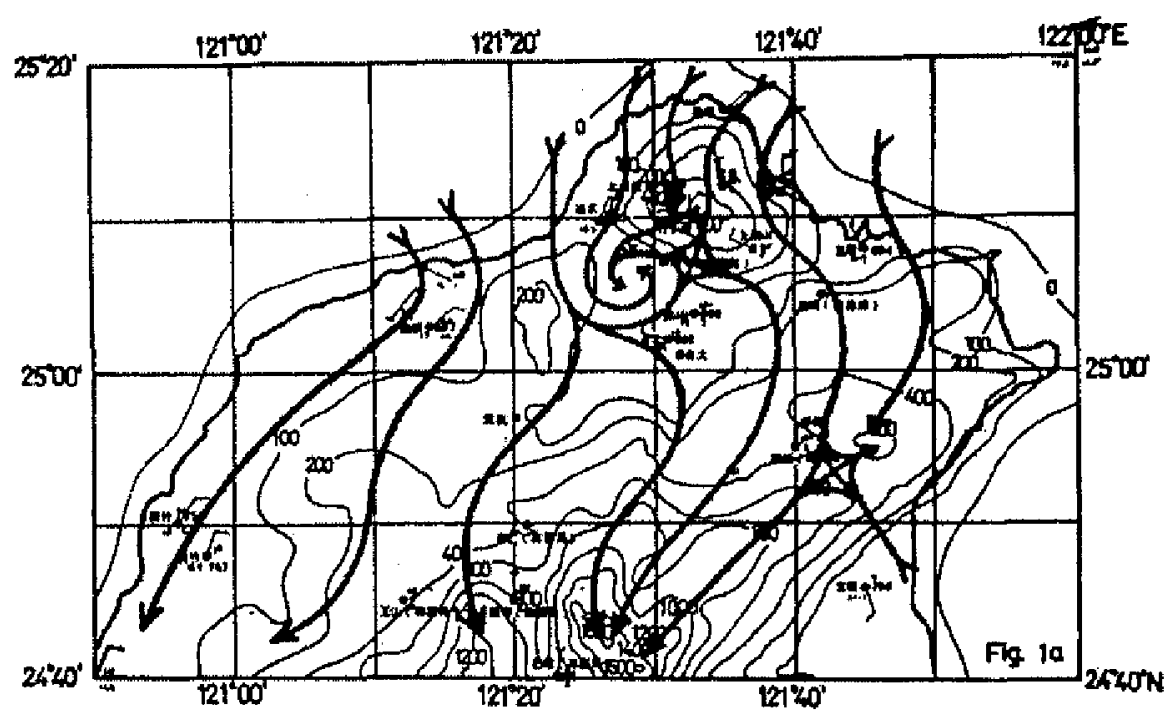

Fig. 3. The average surface streamlines over the northern part of Taiwan during the winter season (adopted from Chen and Tsay, 1983).

rent collection of rainwater in Taipei City was performed. All of these cloud events were associated with frontal passages. Event $\mathrm{D}$ is further divided into Cases $\mathrm{Dl}$ and $\mathrm{D} 2$ in order to match the daily collection of rainwater because it last for more than 40 hours. Table 2 summarizes the chemistry of the cloud water and rainwater. The average values and their standard deviations for cloud water chemistry are based on hourly samples for each cloud event. The followings will present our quantitative analysis of both cloud and precipitation chemistry.

\subsection{Chemical Composition of Cloud Water and Rainwater}

As shown in Table 2, the average $\mathrm{pH}$ of the six cloud events ranged between 3.55-4.31, while it was between 3.82 and 5.89 for rainwater. In our case, the acidity of cloud water was generally higher than that of rainwater. Table 2 also lists the relative contribution of individual ions to total ions. Except for Case $\mathrm{E}$, the principal components in cloud water were found to be seasalt $\left(\mathrm{Na}^{+}\right.$and $\left.\mathrm{Cl}^{-}\right)$and $\mathrm{SO}_{4}^{2-}$, each contributing $17-31 \%, 17-33 \%$ and $15-29 \%$ of total ions, respectively. The former two ions essentially originate from the ocean, while, in addition to natural sources, the later is converted from anthropogenic $\mathrm{SO}_{4}{ }^{2-}$ (Seinfeld, 1986). Meanwhile, excluding Case $\mathrm{D} 2, \mathrm{NH}_{4}{ }^{+}$played a minor role, only accounting for less than $12 \%$ of total ions. Generally speaking, agricultural and industrial activities are the origins of $\mathrm{NH}_{4}^{+}$. For instance, $\mathrm{NH}_{4}{ }^{+}$is the component of fertilizer and product of animal waste (Al-Momani et al., 1995). For industrial sources, $\mathrm{NH}_{3}$ can be present in emissions from combustion (Chow, 1995). Hence, $\mathrm{NH}_{4}^{+}$can be thought of as an important indicator of local emissions. The cloud droplets collected at our site should be, to a lesser extent, contaminated by local sources. By contrast, for rainwater, $\mathrm{SO}_{4}{ }^{2 \cdot}$ and $\mathrm{NH}_{4}{ }^{+}$were the dominant ions, followed by seasalt and $\mathrm{NO}_{3}{ }^{-}$ 
Table 1. Information on cloud events studied on this work.

\begin{tabular}{cccccc}
\hline \multirow{2}{*}{ Event } & \multicolumn{2}{c}{ Start } & \multicolumn{2}{c}{ End } & Duration \\
\cline { 2 - 6 } & Time & Date & Time & Date & (hour) \\
\hline A & 0800 & $1 / 26 / 96$ & 0800 & $1 / 27 / 96$ & 24 \\
B & 1000 & $2 / 28 / 96$ & 1800 & $2 / 28 / 96$ & 8 \\
C & 0820 & $2 / 17 / 97$ & 0620 & $2 / 18 / 97$ & 22 \\
D & 1600 & $2 / 4 / 98$ & 0800 & $2 / 6 / 98$ & 40 \\
E & 1730 & $2 / 15 / 98$ & 2000 & $2 / 15 / 98$ & 3.5 \\
\hline
\end{tabular}

a. Event D last for $\mathbf{4 0}$ hours and was further divided into two cases D1 and D2 for later discussion since rainwater collection is on a daily basis. The cut point between $\mathrm{D} 1$ and $\mathrm{D} 2$ was at 8:00, 2/5/98.

- The $\mathrm{NO}_{3}{ }^{-}$is mainly converted through oxidation reactions from its precursor $\mathrm{NO}_{x}$, which is primarily due to the use of fossil fuels (Seinfeld, 1986). According to Table 2, for all cases, relative contributions of $\mathrm{NO}_{3}{ }^{-}$and $\mathrm{NH}_{4}^{+}$to total ions in rainwater are significantly higher than those in cloud water, suggesting the below-cloud scavenging of local pollutants by raindrops. Meanwhile, the relative contribution of seasalt ions to total ions drops dramatically from cloud droplets to raindrops. This result further supports the addition of local pollutants to rainwater. Evidently, the cloud droplets forming at the peak of Mt. Bamboo may have become loaded with atmospheric pollutants primarily originating from long-range transport. When they grow and subsequently fall as raindrops, atmospheric pollutants can be scavenged below the cloudbase. Thereby, chemical composition of rainwater is altered owing to the addition of local pollutants.

\subsection{Estimates of Below-cloud Scavenging of Pollutants by Raindrops}

As generally observed (Saxena and Lin, 1990; Castillo et al., 1983) in cloud water and rainwater, ion concentrations for the former were usually higher than those for the latter. This difference results from the dilution effect of raindrops when they form from the growth of cloud droplets. Because sulfate particles are the most effective cloud condensation nuclei, the tiny cloud droplets in general contains relatively concentrated sulfates. In the course of the condensational growth of cloud, more sulfates are formed through heterogeneous oxidation of $\mathrm{SO}_{2}$ (Seinfeld, 1986). Later, precipitation occurs as cloud droplets keep growing (e.g., selfgrowth or collection by larger hydrometers) and become heavy enough to overcome the updrafts. Then, the rainwater would be expected to have lower ion concentrations than cloud water. Concurrently, below-cloud scavenging of air pollutants by falling raindrops will enhance the concentrations of these ions in rainwater. Nevertheless, the ionic concentrations in rainwater are still relatively low, compared with cloud water because of large volumetric ratio 
Table 2. Statistical summary of cloud and precipitation chemistry measured at Mt. Bamboo and Taipei city, respectively.

\begin{tabular}{|c|c|c|c|c|c|c|c|c|c|c|c|c|c|c|c|c|}
\hline Case & Type & & Rain & LWC & $\mathrm{pH}$ & $\mathrm{Cl}$ & $\mathrm{NO}_{3}{ }^{-}$ & $\mathrm{SO}_{4}^{2-}$ & nss-SO ${ }_{4}^{2-a}$ & $\mathrm{H}^{+}$ & $\mathrm{NH}_{4}{ }^{+}$ & $\mathrm{Na}^{+}$ & $\mathrm{K}^{+}$ & $\mathrm{Mg}^{2+}$ & $\mathrm{Ca}^{2+}$ & Sum \\
\hline \multirow[t]{2}{*}{ A } & Cloud & $\begin{array}{c}\mu \\
\sigma \\
\% \text { of sum }\end{array}$ & & 0.27 & $\begin{array}{l}4.13 \\
0.36\end{array}$ & $\begin{array}{r}273.0 \\
226.6 \\
30.7\end{array}$ & $\begin{array}{r}20.1 \\
16.3 \\
2.3\end{array}$ & $\begin{array}{r}139.5 \\
109.8 \\
15.7\end{array}$ & $\begin{array}{r}105.5 \\
81.9 \\
11.9\end{array}$ & $\begin{array}{r}71.9 \\
51.0 \\
8.1\end{array}$ & $\begin{array}{r}29.9 \\
24.7 \\
3.4\end{array}$ & $\begin{array}{r}279.7 \\
259.4 \\
31.4\end{array}$ & $\begin{array}{l}7.5 \\
5.5 \\
0.8\end{array}$ & $\begin{array}{r}49.9 \\
43.5 \\
5.6\end{array}$ & $\begin{array}{r}18.6 \\
16.0 \\
2.1\end{array}$ & 995.6 \\
\hline & Rain & $\underset{\% \text { of sum }}{\mu}$ & 8.6 & & 4.06 & $\begin{array}{r}108.7 \\
14.2\end{array}$ & $\begin{array}{r}66.1 \\
8.7\end{array}$ & $\begin{array}{r}175.6 \\
23.0\end{array}$ & $\begin{array}{r}162.3 \\
21.2\end{array}$ & $\begin{array}{l}87.1 \\
11.4\end{array}$ & $\begin{array}{r}152.6 \\
20.0\end{array}$ & $\begin{array}{r}110.2 \\
14.4\end{array}$ & $\begin{array}{l}6.1 \\
0.8\end{array}$ & $\begin{array}{r}24.1 \\
3.2\end{array}$ & $\begin{array}{r}33.9 \\
4.4\end{array}$ & 926.6 \\
\hline \multirow[t]{2}{*}{ B } & Cloud & . & & 0.38 & $\begin{array}{l}3.55 \\
2.15\end{array}$ & $\begin{array}{r}336.5 \\
115.6 \\
18.4\end{array}$ & $\begin{array}{r}108.7 \\
25.2 \\
5.9\end{array}$ & $\begin{array}{r}532.6 \\
71.0 \\
29.1\end{array}$ & $\begin{array}{r}457.7 \\
160.3 \\
25.0\end{array}$ & $\begin{array}{r}97.6 \\
35.4 \\
5.3\end{array}$ & $\begin{array}{r}203.3 \\
60.4 \\
11.1\end{array}$ & $\begin{array}{r}356.2 \\
124.7 \\
19.5\end{array}$ & $\begin{array}{r}29.5 \\
3.1 \\
1.6\end{array}$ & $\begin{array}{r}71.7 \\
21.3 \\
3.9\end{array}$ & $\begin{array}{r}91.5 \\
12.8 \\
5.0\end{array}$ & 2285.2 \\
\hline & Rain & & 7.5 & & 3.82 & $\begin{array}{l}92.3 \\
10.8\end{array}$ & $\begin{array}{l}97.2 \\
11.4\end{array}$ & $\begin{array}{r}200.9 \\
23.5\end{array}$ & $\begin{array}{r}191.1 \\
22.3\end{array}$ & $\begin{array}{r}151.4 \\
17.7\end{array}$ & $\begin{array}{r}179.7 \\
21.0\end{array}$ & $\begin{array}{r}80.8 \\
9.4\end{array}$ & $\begin{array}{l}6.1 \\
0.7\end{array}$ & $\begin{array}{r}20.4 \\
2.4\end{array}$ & $\begin{array}{r}27.0 \\
3.2\end{array}$ & 1046.7 \\
\hline \multirow[t]{2}{*}{ C } & Cloud & & & $0.2 !$ & $\begin{array}{l}4.02 \\
0.18\end{array}$ & $\begin{array}{r}488.6 \\
412.9 \\
33.3\end{array}$ & $\begin{array}{r}42.8 \\
29.9 \\
2.9\end{array}$ & $\begin{array}{r}228.4 \\
158.2 \\
15.5\end{array}$ & $\begin{array}{r}192.6 \\
135.0 \\
13.1\end{array}$ & $\begin{array}{r}87.3 \\
37.5 \\
5.9\end{array}$ & $\begin{array}{r}78.1 \\
38.6 \\
5.3\end{array}$ & $\begin{array}{r}374.1 \\
302.3 \\
25.5\end{array}$ & $\begin{array}{r}15.5 \\
8.5 \\
1.1\end{array}$ & $\begin{array}{r}90.0 \\
64.3 \\
6.1\end{array}$ & $\begin{array}{r}63.8 \\
46.8 \\
4.3\end{array}$ & 1661.3 \\
\hline & Rain & & 9.9 & & 4.00 & $\begin{array}{r}174.3 \\
20.9\end{array}$ & $\begin{array}{r}28.7 \\
3.4\end{array}$ & $\begin{array}{r}162.5 \\
19.5\end{array}$ & $\begin{array}{r}139.8 \\
16.8\end{array}$ & $\begin{array}{r}100.0 \\
12.0\end{array}$ & $\begin{array}{l}84.2 \\
10.1\end{array}$ & $\begin{array}{r}187.4 \\
22.5\end{array}$ & $\begin{array}{r}10.1 \\
1.2\end{array}$ & $\begin{array}{r}41.9 \\
5.0\end{array}$ & $\begin{array}{r}42.9 \\
5.2\end{array}$ & 971.9 \\
\hline \multirow[t]{2}{*}{ D1 } & Cloud & & & 0.22 & $\begin{array}{l}4.15 \\
0.12\end{array}$ & $\begin{array}{r}164.5 \\
59.5 \\
25.1\end{array}$ & $\begin{array}{r}24.8 \\
7.8 \\
3.8\end{array}$ & $\begin{array}{r}150.7 \\
45.6 \\
23.0\end{array}$ & $\begin{array}{r}139.5 \\
41.7 \\
20.2\end{array}$ & $\begin{array}{l}72.7 \\
21.1 \\
11.1\end{array}$ & $\begin{array}{r}62.7 \\
30.3 \\
9.6\end{array}$ & $\begin{array}{r}153.0 \\
38.1 \\
23.3\end{array}$ & $\begin{array}{l}7.0 \\
2.7 \\
1.1\end{array}$ & $\begin{array}{r}15.0 \\
13.1 \\
2.3\end{array}$ & $\begin{array}{l}6.1 \\
6.2 \\
0.9\end{array}$ & 656.5 \\
\hline & Rain & & 5.2 & & 4.34 & $\begin{array}{l}31.8 \\
14.3\end{array}$ & $\begin{array}{r}14.6 \\
6.5\end{array}$ & $\begin{array}{l}55.1 \\
24.7\end{array}$ & $\begin{array}{l}52.5 \\
23.2\end{array}$ & $\begin{array}{l}45.7 \\
20.5\end{array}$ & $\begin{array}{l}44.7 \\
20.0\end{array}$ & $\begin{array}{r}21.6 \\
9.7\end{array}$ & $\begin{array}{l}2.5 \\
1.1\end{array}$ & $\begin{array}{l}5.1 \\
2.3\end{array}$ & $\begin{array}{l}2.1 \\
0.9\end{array}$ & 223.2 \\
\hline \multirow[t]{2}{*}{ D2 } & Cloud & & & 0.24 & $\begin{array}{l}4.31 \\
0.19\end{array}$ & $\begin{array}{l}84.2 \\
76.4 \\
18.2\end{array}$ & $\begin{array}{r}30.6 \\
17.1 \\
6.6\end{array}$ & $\begin{array}{r}113.0 \\
58.5 \\
24.4\end{array}$ & $\begin{array}{r}102.9 \\
51.3 \\
22.1\end{array}$ & $\begin{array}{l}53.1 \\
22.1 \\
11.5\end{array}$ & $\begin{array}{l}84.4 \\
49.9 \\
18.2\end{array}$ & $\begin{array}{l}79.7 \\
66.2 \\
17.2\end{array}$ & $\begin{array}{l}5.1 \\
2.3 \\
1.1\end{array}$ & $\begin{array}{l}9.2 \\
8.8 \\
2.0\end{array}$ & $\begin{array}{l}3.5 \\
1.7 \\
0.8\end{array}$ & 462.7 \\
\hline & Rain & & 7.6 & & 4.68 & $\begin{array}{r}10.2 \\
8.5\end{array}$ & $\begin{array}{r}10.6 \\
8.8\end{array}$ & $\begin{array}{l}37.6 \\
31.3\end{array}$ & $\begin{array}{l}37.2 \\
31.3\end{array}$ & $\begin{array}{l}20.9 \\
17.4\end{array}$ & $\begin{array}{l}34.7 \\
28.8\end{array}$ & $\begin{array}{l}3.4 \\
2.9\end{array}$ & $\begin{array}{l}1.9 \\
1.6\end{array}$ & $\begin{array}{l}0.7 \\
0.6\end{array}$ & $\begin{array}{l}0.3 \\
0.3\end{array}$ & 120.2 \\
\hline \multirow[t]{2}{*}{$E$} & Cloud & & & 0.28 & $\begin{array}{l}3.62 \\
0.09\end{array}$ & $\begin{array}{r}149.3 \\
53.3 \\
17.1\end{array}$ & $\begin{array}{r}66.8 \\
22.0 \\
7.7\end{array}$ & $\begin{array}{r}230.8 \\
24.7 \\
26.4\end{array}$ & $\begin{array}{r}212.5 \\
18.1 \\
24.3\end{array}$ & $\begin{array}{r}242.6 \\
50.2 \\
27.8\end{array}$ & $\begin{array}{r}21.1 \\
4.7 \\
2.4\end{array}$ & $\begin{array}{r}151.3 \\
54.4 \\
17.3\end{array}$ & $\begin{array}{l}2.0 \\
0.1 \\
0.2\end{array}$ & $\begin{array}{l}4.9 \\
2.0 \\
0.6\end{array}$ & $\begin{array}{l}4.1 \\
1.0 \\
0.5\end{array}$ & 1085.3 \\
\hline & Rain & & 2.5 & & 5.89 & $\begin{array}{l}48.7 \\
13.8 \\
\end{array}$ & $\begin{array}{l}35.9 \\
10.2 \\
\end{array}$ & $\begin{array}{l}78.1 \\
22.2 \\
\end{array}$ & $\begin{array}{l}73.9 \\
21.0 \\
\end{array}$ & $\begin{array}{l}1.3 \\
0.4 \\
\end{array}$ & $\begin{array}{r}134.9 \\
38.3 \\
\end{array}$ & $\begin{array}{r}34.8 \\
9.9 \\
\end{array}$ & $\begin{array}{l}5.8 \\
1.7 \\
\end{array}$ & $\begin{array}{l}6.7 \\
1.9 \\
\end{array}$ & $\begin{array}{l}5.8 \\
1.6 \\
\end{array}$ & 425.9 \\
\hline
\end{tabular}

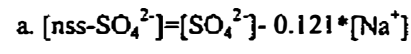


of raindrops to cloud droplets. Hence, we may estimate the dilution effect by comparing the concentrations of a tracer between rainwater and cloud water. Such a tracer, for instance, can be the $\mathrm{Na}^{+}$since its natural origin is from the ocean.

In this study, coincident sampling of cloud water at the peak of Mt. Bamboo and of rainwater at the ground level (see site description in Section 2) was performed through two different experiments. Here, we attempt to use both datasets to estimate the below-cloud scavenging of pollutants by raindrops. We assume that the clouds observed at our site preserved their chemical properties as they extend horizontally tens of kilometers to shelter the Taipei basin, as these clouds were well organized and distributed in accordance with the frontal passage (for instance, see Fig. 2). This may not be true for the case that the entrainment of air pollutants below cloudbase happens. In practice, cloud properties, for instance, $\mathrm{SO}_{4}{ }^{2-}$, also cannot remain unchanged at different positions in a cloud. However, in our site, the cloud chemistry was continuously observed. The ensemble averages (which are used throughout this study) of these cloud properties of individual samples in time somewhat represent the bulk properties of clouds in space, at least, at the same altitude as our site. In spite of these uncertainties, the above assumption should be valid to some extent. Thus, the dilution factor $(D F)$ of a specific tracer $X$ in cloud droplets with respect to raindrops can be obtained by calculating the ratio of the equivalent concentration of $X$ in cloud water to that in rainwater:

$$
D F=\frac{[X]_{c}}{[X]_{r}-[X]_{p}}
$$

where $c, r$ and $p$ denote the cloud water, rainwater and particle phase, respectively. The $[X]_{p}$ is due to the below-cloud scavenging of $X$ in the form of aerosol particles by raindrops. The $X$ can be the $\mathrm{Na}^{+}$, which originates from the ocean. Therefore, neglecting the absorption of gaseous $i$, the portion $(f(i))$ of $[i]$, which results from below-cloud scavenging of a species $i$ in the form of aerosol particles by raindrops, can be expressed as:

$$
f(i)=1-\frac{[i]_{c}}{[i]_{r}} \bullet \frac{1}{D F}
$$

For simplicity, we neglect the contribution of $\mathrm{Na}^{+}$-containing aerosols to raindrops. However, it is not necessarily the case that more or less, seasalt aerosols should have already existed in the air below the cloudbases above Taipei basin. Thus, the $D F$ calculated by Eq. (1) is substantially underestimated since $\left[\mathrm{Na}^{+}\right]_{p}$ is presumed to be zero. The $f$ somewhat represents the contribution from local pollutants, whereas, the portion $(l-f)$ is due to in-cloud scavenging. As along as our site is not contaminated by local sources, the latter portion of pollutants in rainwater can be attributed to long-range transport. This ideal situation is evaluated below.

According to the chemistry of cloud water and rainwater listed in Table 2, we calculate 
the $D F$, $f\left(\right.$ nss- $\left.-\mathrm{SO}_{4}{ }^{2-}\right), f\left(\mathrm{NO}_{3}{ }^{-}\right)$and $f\left(\mathrm{NH}_{4}^{+}\right)$for 6 cases. The results are listed in Table 3. For Cases $\mathrm{A}$ and $\mathrm{D} 2$, nss- $\mathrm{SO}_{4}^{2-}, \mathrm{NO}_{3}^{-}$and $\mathrm{NH}_{4}^{+}$in rainwater are highly enhanced by below-cloud scavenging, resulting in relatively higher $f$, as shown in Tables 2 and 3. For the former event, their contribution to total ions increased from 15.7, 2.3, and 3.4\% for cloud water to $23.0,8.7$ and $20.0 \%$ for rainwater, respectively. By contrast, seasalt ions decreased at least $50 \%$ both in their concentrations and contributions to total ions. Similar variations can also be seen in Case D2. The former event was more contaminated than the latter one. Case B had the highest concentrations of $\mathrm{SO}_{4}^{2 \cdot}$ and $\mathrm{NO}_{3} \cdot$ for both cloud water and rainwater among all cases. Meanwhile, excessive $\mathrm{NH}_{4}^{+}$over $\mathrm{NO}_{3}^{-}$can only neutralize a part of the $\mathrm{SO}_{4}^{2-}$, consequently, leading to the highest acidity as well. About half of [nss- $\left.\mathrm{SO}_{4}{ }^{2-}\right]_{r}$ was attributed to below-cloud scavenging, compared with $2 / 3$ of $\left[\mathrm{NO}_{3}^{-}\right]_{r}$ and $\left[\mathrm{NH}_{4}^{+}\right]_{r}$. By contrast, Case $\mathrm{C}$ had the largest concentrations of $\mathrm{Na}^{+}$and $\mathrm{Cl}^{-}$among all cases, both accounting for around 60 and $40 \%$ of total ions for cloud water and rainwater, respectively. In this case, $\mathrm{SO}_{4}{ }^{2-}$ still played a major role in controlling the acidity. The $\mathrm{NO}_{3}{ }^{-}$was evidently a minor component. It was primarily derived from in-cloud scavenging $(1-f=0.69)$, as well as nss- $\mathrm{SO}_{4}^{2 \cdot}$.

As to Cases Dl and D2, they were derived from cloud event D (see Table 1). For cloud water, seasalt and $\mathrm{SO}_{4}{ }^{2-}$ were the principal ions for $\mathrm{D} 1$. However, the relative contribution of $\mathrm{NH}_{4}^{+}$to total ions increased from $9.6 \%$ for D1 to $18.2 \%$ for D2 (see Table 2), and it became equivalent to seasalt on the second day (D2), indicating the relative enhancement of local sources, e.g., the biological products from the National Park. This situation was even more significant for rainwater. According to Table 3, it is observed that $f\left(\mathrm{NO}_{3}{ }^{-}\right)$and $f\left(\mathrm{NH}_{4}^{+}\right)$have a gentle increase from $\mathrm{Dl}$ to $\mathrm{D} 2$, while $\mathrm{f}\left(\mathrm{nss}-\mathrm{SO}_{4}{ }_{4}^{2 \cdot}\right.$ ) increased almost by half in the second day. At the end of this frontal passage, the clouds became relatively cleaner (see the decrease in ion concentrations for Case D2 in Table 2), whereas local emissions relatively enhanced the sulfur compounds in rainwater. Unlike the above cases, rainwater for Case $\mathrm{E}$ had its $\mathrm{pH}>5.6$, the $\mathrm{CO}_{2}$ equilibrated value, although the $\mathrm{pH}$ of cloud water was as low as 3.62 , the second highest acidity among all cases. In this case, $\mathrm{SO}_{4}{ }^{2 \cdot}$ and $\mathrm{NO}_{3}{ }^{-}$were significantly elevated, compared with Case A. Meanwhile, they were the major contributors to the acidity of cloud water. In

Table 3. Dilution factor $(D F)$ and contribution $(f)$ of below-cloud scavenging by raindrops to nss- $\mathrm{SO}_{4}{ }^{2}, \mathrm{NO}_{3}{ }^{-}$and $\mathrm{NH}_{4}{ }^{+}$in rainwater.

\begin{tabular}{lcccc}
\hline Case & $D F$ & $f\left(\mathrm{nss}-\mathrm{SO}_{4}{ }^{2-}\right)$ & $f\left(\mathrm{NO}_{3}{ }^{-}\right)$ & $f\left(\mathrm{NH}_{4}{ }^{+}\right)$ \\
\hline $\mathrm{A}$ & 2.54 & 0.74 & 0.88 & 0.92 \\
$\mathrm{~B}$ & 4.41 & 0.46 & 0.75 & 0.74 \\
$\mathrm{C}$ & 2.00 & 0.31 & 0.25 & 0.54 \\
$\mathrm{D} 1$ & 7.10 & 0.63 & 0.76 & 0.80 \\
$\mathrm{D} 2$ & 23.17 & 0.88 & 0.88 & 0.89 \\
$\mathrm{E}$ & 4.35 & 0.34 & 0.57 & 0.96 \\
\hline
\end{tabular}


addition, minor cations accounted for less than $4 \%$ of total ions. By contrast, for rainwater, excessive $\mathrm{NH}_{4}^{+}$over $\mathrm{SO}_{4}{ }^{2-}$ and $\mathrm{NO}_{3}{ }_{3}^{-}$increased the alkalinity of rainwater (see Table 2). According to Table 3, it is found that for Case $\mathrm{E} \mathrm{NH}_{4}^{+}$originated mostly from below-cloud scavenging $(f=0.96)$, whereas, most of nss- $\mathrm{SO}_{4}{ }^{2-}$ was attributed to in-cloud scavenging $(1-f=$ $0.66)$.

In summary, the $D F$ varied between $2-23$ for the above 6 cases. The $f\left(n s s-\mathrm{SO}_{4}{ }^{2-}\right), f\left(\mathrm{NO}_{3}\right.$. ) and $f\left(\mathrm{NH}_{4}^{+}\right)$ranged between 0.31-0.88, 0.25-0.88 and 0.54-0.96, respectively. Overall, most of $\left[\mathrm{NH}_{4}^{+}\right]_{r}$ were evidently attributed to below-cloud scavenging, again reflecting their origins from local sources. Meanwhile, $\left[\mathrm{NH}_{4}^{+}\right]_{r}$ was accounted for at least $75 \%$ by the same scavenging mechanism, except for Cases $\mathrm{C}$ and $\mathrm{E}$. In contrast, a large portion of $\left[\mathrm{nss}-\mathrm{SO}_{4}{ }_{4}{ }^{2}\right]_{r}$ resulted from in-cloud scavenging. In comparison with $\mathrm{NH}_{4}{ }^{+}$and $\mathrm{NO}_{3}{ }^{-}$, relatively higher amount of nss- $\mathrm{SO}_{4}{ }^{2-}$ was obviously derived from long-range transport.

These results are dependent mainly on two assumptions, the horizontal homogeneity of the layer of clouds and no below-cloud scavenging of seasalts. The former assumption may be held unless strong entrainment occurs, especially near the proximity of cloud boundaries. For the latter, it is probably not true since in the winter northeast monsoon flows bring seasalt aerosols into the basin, later, accumulating in the air. For instance, if $\left[\mathrm{Na}^{+}\right]_{\rho} /\left[\mathrm{Na}^{+}\right]_{r}=0.1$, then $D F$ will increase to 2.82 for Case A (around $11 \%$ increase). Consequently, $f\left(n s s-\mathrm{SO}_{4}{ }^{2-}\right), f\left(\mathrm{NO}_{3}^{-}\right.$ ) and $f\left(\mathrm{NH}_{4}^{+}\right)$increase slightly to $0.77,0.89$ and 0.93 , respectively. Based on these two assumptions, those $f \mathrm{~s}$ listed in Table 3 should represent the minimum contribution of belowcloud scavenging of the corresponding pollutants by raindrops.

\section{CONCLUDING REMARKS}

In this paper, we have demonstrated the usefulness of a simple and semi-quantitative scheme for estimating the effects of below-cloud scavenging of pollutants on the composition of rainwater collected on the ground level of Taipei City, based on the cloud chemistry observed at the peak of the Mt. Bamboo. In addition, we have also learned of a possibility of the long-range transport of sulfur compounds through frontal clouds. By contrast, the nitrogen compounds, including $\mathrm{NH}_{4}^{+}$and $\mathrm{NO}_{3}^{-}$in rainwater collected in Taipei during the wintertime frontal passages, can be primarily attributed to local sources.

Acknowledgements Our work was supported by the National Science Council of Taiwan under the contracts No. NSC 86-2111-M-008-AP3, 87-2111-M-008-028-AP3 and 88-2111M-008-016-AP3, and by the Central Weather Bureau under the contract No. 85-2M-01. The field experiments of cloud chemistry were performed with the help of many graduate and undergraduate students. The data of precipitation chemistry was provided by Prof. F.-T. Jeng, the Graduate Institute of Environmental Engineering, National Taiwan University. The authors are also grateful to two anonymous reviewers for providing insightful comments that led to substantial strengthening the contents of this paper. 


\section{REFERENCES}

Al-Momani, I. F., O. Y. Ataman, M. A. Anwari, S. Tuncel, C. Kse, and G. Tuncel,1995: Major ion composition of wet and dry deposition in the eastern Mediterranean basin. Sci. Total Environ., 164, 75-85.

Castilo, R. A., J. E. Jiusto, and E. McLaren, 1983: The $\mathrm{pH}$ and ion composition of stratiform cloud water. Amos. Environ., 17, 1497-1505.

Chen, J.-S., N.-H. Lin, C.-M. Peng, and F.-T. Jeng, 1996: Acidic deposition on Taiwan and associated precipitation systems. In Proceedings of International Conference on Acid Deposition in East Asia, Taipei, Taiwan, May 28-30, 1996.

Chen, W.-K., and C.-Y. Tsay, 1983: The climate of Yang Ming Shan National Park. In Science Report, 4, available from the Department of Atmospheric Sciences, National Taiwan University.

Choularton, T. W., R. W. CoIvile, K. N. Bower, et al., 1997: The Great Dun Fell Cloud Experiment 1993: An overview. Atmos. Environ., 31, 2393-2405.

Chow, J. C., 1995: Measurement methods to determine compliance with ambient air quality standards for suspended particles. J. Air Waste Manag. Assoc., 45, 320-382.

Collett, J. L., Jr., B. C., Jr., Daube, and M. R. Hoffmam, 1990: The chemical composition of intercepted cloudwater in the Sierra Nevada. Atmos. Environ., 24, 959-972.

Fuzzi, S., M. C. Facchini, G. Orsi, et al., 1992: The Po Valley Fog Experiment 1989: An overview. Tellus, 44B, 448-469

Hegg, D. A., and P. V. Hobbs., 1986: Sulfate and nitrate chemistry in cumuliform clouds. Atmos. Environ., 20, 901-909.

Jeng, F.-T., 1998: A Study of Acidic Deposition on Taiwan. Final Report to EPA, NSC87EPA-P-008-001, available from the library of the EPA of Taiwan.

Katz, U. and D. Miller, 1985: Development and Evaluation of Cloud Water Collectors. Final Report to Electric Power Research Institute, Inc., Atlanta, Georgia (available from Desert Research Institute, Reno, Nevada).

Leaitch, W. R., J. W. Strapp, H. A. Wiebe and G. A. Isaac, 1983: Measurements of scavenging transformation of aerosol inside cumulus. In Precipitation Scavenging, Dry Deposition and Resuspension (edited by H. R. Pruppacher, R. G. Semonin and W. G. N. Slinn), Elsevier, New York, 53-69.

Lin, N.-H., H.-M. Lee, and M.-B. Chang, 1999: Evaluation of the characteristics of acid precipitation in Taipei, Taiwan using cluster analysis. Water, Air \& Soil Pollut., 113, 241260.

Mohnen, V., J. Santroch, and R. Vet, 1994: Report of the Wrokshop on Precipitation Chemistry Laboratory Techniques. Global Atmosphere Watch, World Meteorological Organization, WMO/TD-No. 685.

NAPAP (National Acid Precipitation Assessment Program), 1991: 1990 Integrated Assessment Report. U.S. Government Printing Office, Washington, D.C., 520 pp.

Saxena, V. K, and N.-H. Lin, 1990: Cloud chemistry measurements and estimates of acidic 
deposition on an above cloudbase coniferous forest. Atmos. Environ., 24, 329-352.

Schemenauer, R. S., C. M. Banic, and N. Urquizo. 1995: High elevation fog and precipitation chemistry in southern Quebec, Canada. Atmos. Environ., 29, 2235-2252

Schumann, T., B. Zinder, and A. Waldvogel, 1988: Aerosol and hydrometer concentrations and their chemical composition during winter precipitation along mountain slope-I. Temporal evolution of the aerosol, microphysical and meteorological conditions. Atmos. Environ., 22, 1443-1459.

Seinfeld, J. H., 1986: Atmospheric Chemistry and Physics of Air Pollution. John Wiley \& Sons, Inc., New York.

Wobrock, W., D. Shell, R. Maser, et al., 1994: The Kleiner Feldberg Cloud Experiment 1990: An overview. J. Atmos. Chem., 19, 3-35. 